\title{
Religionswissenschaft as Colonialist Discourse: The Case of Rudolf Otto
}

TIM MURPHY

University of Alabama

\begin{abstract}
The dominant approach to the study of religion known as the phenomenology of religion's core assumption was that underlying the multiplicity of historical and geographically dispersed religions was an ultimately metaphysical, trans-historical substratum, called 'man', Geist, or 'consciousness'. This transhistorical substratum is an expressive agent with a uniform, essential nature. By reading the data of religion as its 'expressions', it is possible to sympathetically understand their meaning. Geist, or 'man', then, is both a philosophy of history and a hermeneutical theory. It also forms a systematic set of representations, which replicate the structure of the asymmetrical relations between Europeans and those colonized by Europeans. The metanarrative of Geist is a narrative of the supremacy - their term, not mine - of white, Christian Europe over black, 'primitive' Africa and 'despotic' Asia. Spirit moves from the South to the North; away from the East to the West. This paper locates Rudolf Otto's work within the structure and history of phenomenological discourse and argues that the science of religion as described there conforms nearly perfectly to the structures of colonial discourse as this has been discussed and analyzed by theorists such as Jacques Derrida and Edward Said.
\end{abstract}

Keywords: Rudolf Otto, colonialism, study of religion, phenomenology of religion

One of the most important methodological approaches to the study of religion throughout most of the discipline's history has been called 'phenomenology of religion', its most famous proponents being Rudolf Otto and Mircea Eliade. So pervasive was this approach that for some time 'phenomenology of religion' (also known in English as 'history of religions') was virtually synonymous with Religionswissenschaft, or the academic study of religion. For example, at the level of department formation, at least in the United States, the discourse of phenomenology of religion played an important, even founding role in legitimizing Religious Studies as an autono- 
mous field. An example of this is given in Thomas Idinopulous' narrative of the founding of a Religious Studies program at the University of Miami (Ohio). When questioned as to why a department should be formed that studies this content-area (rather than being studied as a subject matter in different, already established disciplines), Idinopulous and his colleagues argued that 'only a religion department could do justice to the study of religion in its totality, wholeness and uniqueness' (Idinopulous 1994, 66). When asked how such a program of study should be undertaken, there was a ready-at-hand reply:

But when we were pressed to defend the particular methods of religious study separate and distinct from the methods of psychology or sociology or history I cannot recall the description of any specific method. In place of method we invoked a trinity of prestigious scholars - Rudolph Otto, Joachim Wach, Mircea Eliade. In our minds these authors had set forth ideas about the distinctive or unique character of religion. For that reason we were convinced that our own academic department was the only place in which religion's 'unique meaning' could be studied and taught, however much religion might be investigated by other university disciplines. (Idinopulous 1994, 66.)

Despite the onslaught of reductionist approaches, Idinopulous remains convinced that 'the central questions about the nature of religion and the study of religion have not changed over the years' (1994, 66-67). The ideas of Otto, Wach, and Eliade still answer these basic questions about the nature of Religious Studies for many scholars, if not all, in the field.

The core philosophical assumption of phenomenology of religion was that underlying the multiplicity of historical and geographically dispersed religions was an ultimately metaphysical, transhistorical substratum, variously called 'man', ${ }^{1}$ Geist, 'mind', or 'consciousness'. This transhistorical substratum is an expressive agent with a uniform, essential nature. As such, by reading the data of the history of religions as 'expressions', it is possible to sympathetically understand them by tapping into, as it were, one's own human subjectivity. Geist, or 'man', then, is the basis for a philosophy of religion, a philosophy of history, and a hermeneutical theory.

It also, however, forms a systematic set of representations, which replicate the structure of the asymmetrical relations between Europeans and those

\footnotetext{
${ }^{1}$ In this article, I follow other theorists and argue that 'man' is not a generic name for the human species but rather a very specific European, modern philosophical configuration that emerges in the wake of the Cartesian revolution; hence the scare quotes. It is also a gendered construct. A similar argument holds for other ostensibly natural categories, such as 'mind', 'experience', or 'consciousness'.
} 
colonized by Europeans. This is what is meant in this article by 'colonialist discourse': any discursive formation which reiterates and validates either as true or as positive, implicitly or explicitly, consciously or unconsciously, the historically determined relationships between colonist and colonizer. As research done in any number of academic fields has shown, this occurs in such areas as film, literature, philosophy, theology, art, language, historiography, biology, culture generally, and yes, both at the first-order level of the practice of religion - mostly vis-à-vis Christian missionaries - but also at the second-order level of the academic study of religion. The latter, I shall argue, has been part of the unfortunate legacy of the work of Rudolf Otto. This article will review the history and structure of the discursive formation of this school by focusing primarily (for the sake of brevity) on one of its most celebrated and oft cited sources, the phenomenological theory of religion espoused by Rudolf Otto, especially as this is contained in his famous work, The Idea of the Holy (1917). This book is often cited by introductory textbooks to the field, by world religion books, by members of the field of Religious Studies, and by scholars in related disciplines such as philosophy and history. It is a convenient site (or cite), typical of a large swath of the discursive field which is authenticated as 'knowledge' by academic institutions, societies, presses, and much of the professional apparatus of the university system.

We must begin with a very brief look at the history of the phenomenology of religion. Like many other scholars of the late nineteenth and early twentieth century, Otto was deeply, if largely indirectly, influenced by G. W. F. Hegel and German Idealism. Among the many ideas derived from German Idealism that pervade the phenomenology of religion is the radical qualitative distinction Hegel posits between nature and Spirit (Geist):

Freedom is the sole truth of Spirit. Matter possess gravity in virtue of its tendency toward a central point. It is essentially composite: consisting of parts that exclude each other. It seeks its Unity out of itself. [...] Spirit, on the contrary, may be defined as that which has its center in itself. It has not a unity outside itself, but has already found it; it exists in and with itself. Matter has its essence out of itself; Spirit is self contained existence (bei sich selbst sein). (Hegel 1956, 17.)

Otto agrees, arguing that ' $[\mathrm{t}]$ he direct experience that spirit has of itself, of its individuality and freedom, of its incomparability with all that is beneath it, is far too constant and genuine to admit of its being put into a difficulty 
by a doctrine which it has itself established' (Otto 1907, 295). ${ }^{2}$ Nature/Matter, as such, cannot attain true self-hood or subjectivity, as the essence of subjectivity is to be 'in-and-for-itself'. Matter's ontological determination is to have its being as 'out-of-itself'. As shall be discussed below, one of the heinous outcomes of this construction of the structural relation between Nature and Spirit becomes evident when it is applied to human beings, some of whom are classified as Naturvolk, while the correlation between Kultur and objektiver Geist is elevated to both a methodological and a metaphysical principle. The result is that 'civilized' peoples are inherently free, while Naturvolk, like Nature/Matter itself, are inherently dependent, having their telos and purpose outside of themselves. This, of course, is a legitimation for the colonization and subordination of the latter by the former. This occurs both in practical terms, where Nature - including Naturvolk - is a repository of resources which exists for Spirit, and in theoretical-scientific terms, where, as objects of inquiry, 'primitive' cultures are the Other by and through which Spirit comes to 'pure self-recognition in absolute otherness' (Hegel 1977, 14; paragraph nr 26). Spirit is both subject and substance, the underlying reality that makes temporality 'history', as opposed to mere change. So, 'higher civilizations' have a history, whereas 'primitives' or Naturvolk, do not.

\section{Spirit Separates from Nature: Hegel and Otto on the History of Religion}

The metaphysical distinction between the inherent qualities of Geist and of Natur functions as a structural principle for Hegel's narrative of the Entwicklung, the development or evolution, of Spirit's reflexive coming to self-consciousness or self-realization. As Spirit develops, it knows itself progressively better - this is, in fact, the measure of its development. So also with religion. A culture's ideas of god or divinity reflect its development of selfhood:

Even as the content, God, determines itself, so on the other side subjective human spirit that has this knowledge determines itself. The principle by which God is defined for human beings is also the principle for how humanity defines itself inwardly, or for humanity in its own spirit. An inferior god or

\footnotetext{
${ }^{2}$ As Adina Davidovich has argued: 'My analysis showed that Otto accepted the Kantian dualism of nature and freedom' (Davidovich 1993, 216). Despite their very real differences, in broad terms Kant and Hegel were more alike than different on the issue of nature vs. mind or Spirit. Davidovich's point adds weight to mine: for Otto the difference between nature and Spirit was extremely important.
} 
a nature god has inferior, natural and unfree human beings as its correlates; the pure concept of God or the spiritual God has as its correlate spirit that is free and spiritual, that actually knows God. (Hegel 1988, 203.)

Otto makes the distinction between Spirit and nature a much more explicit part of his conception of the science of religion. He argues that this Idealist concept of history is necessary for there to be a science of religion, and history can only be understood if it possesses an underlying unity. In the human domain, this unity must be spirit:

There is something presupposed by history as such - not only the history of mind or spirit, with which we are here concerned - which alone makes it history, and this is the existence of a quale, something with a potentiality of its own, capable of becoming, in the special sense of coming to be that to which it was predisposed and predetermined. [...] it must already be something if it is to really become anything. [...] In short, to propose a history of mind [Geist] is to presuppose a mind or spirit determinately qualified; to profess to give a history of religion is to presuppose a spirit specifically qualified for religion. (Otto 1958, 175-176.)

For Otto, as for Hegel, Spirit is the substance and subject of history, the 'it' that makes any history a history of something. For there to be a history of religion, the subject of that history must be something, i.e., have a determinate nature (Wesen), which can be the subject of such a history. Without the concept of an essence to history, only 'mere aggregation' is possible:

An oak-tree can become, and thus have a sort of 'history': whereas a heap of stones cannot. The random addition and subtraction, displacement and rearrangement, of elements in a mere aggregation can certainly be followed in narrative form, but this is not in the deeper sense an historical narrative. (Otto 1958, 176.)

There must be an 'it' which is the subject of the process of becoming, and this 'it' is that which gives the process of becoming identity, rather than being 'mere aggregation'.

For human beings, clearly this 'it' cannot be an empirical entity - that would make it a 'mere aggregation', and not the development of an essential nature. It must be something which is not bound to a specific time, place, or human production, i.e., it must be non-material and transcendental in nature. 
This, of course, is exactly what Otto claims in his famous definition of the 'Holy': 'the "holy" in the fullest sense of the word is a combined, complex category. [...] But in both - and the assertion must be strictly maintained against all sensationalism and naturalism - it a purely a priori category', and with it 'we are referred away from all sense-experience back to an original and underivable capacity of the mind implanted in the "pure reason" independently of all perception.' (Otto 1958, 112.) Geist, not Natur, is the source and the essence of the Holy.

In his articulation of the concept of the a priori nature of the holy, Otto follows Kant in differentiating between sense impressions, whose only role even in empirical knowledge consists of 'giving merely the occasion' for the formation of concepts and 'our own faculty of cognition' (Otto 1958, 113) which is innate and part of the a priori structure of consciousness as such. 'The numinous is of the latter kind. It issues from the deepest foundation of cognitive apprehension that the soul possesses.' (Otto 1958, 113.) As such:

We find [...] involved in the numinous experience, beliefs and feelings qualitatively different from anything that 'natural' sense-perception is capable of giving us [...] there is never any question of the transformation of one class of percepts into a class of [mental/conceptual] entities qualitatively other (Otto 1958, 113).

'Mere' sense-perception is not, again, the source of the Holy. It is rein, 'pure', i.e., removed from and literally categorically distinct from Natur.

This a priori realm of 'pure reason', then, in turn becomes the criterion by which the value of religions is measured. He defines 'rational' thusly: 'An object that can thus be thought conceptually may be termed rational [...] and a religion which recognizes and maintains such a view of God is in so far a "rational" religion. Only on such terms is belief possible in contrast to mere feeling.' (Otto 1958, 1.) Put bluntly, Geist thinks; Natur feels, 'feeling' being derived from the senses, i.e., the body, i.e., nature.

The notion of the holy as an a priori - and therefore universal - feature of consciousness as such plays a critical role in Otto's view of religion. As Phillip Almond explains:

The relative value of religions can be measured [then] according to the extent to which they actualize the religious a priori. The criteria for this evaluation are determined from 'within' religion, that is, by the degree to which the 
Holy is revealed in each tradition. The religious a priori thus affords an 'objective' standard against which its various manifestations can be measured; consequently, the history and comparison of religions can be a theology of religions. (Almond 1984, 113.)

But also a science of religion, or Religionswissenschaft. As the a priori is categorically distinct from sense-perception, the Holy is categorically distinct from Natur. As such, the criterion of the Entwicklung, the historical development or evolution of a religion is, as with Hegel, the degree to which it separates itself from the various aspects of Natur. Nature religions will be the lowest; 'spiritual' religions the highest forms of religion.

Consequently, such binary distinctions as Spirit and nature, a priori and a posteriori, reason and sense (or reason and feeling), allow Otto to emplot a history of religion (which is also a history of consciousness or Spirit) from 'primitives', for whom genuine spiritual experience is 'confounded with "natural" feelings' (Otto 1958, 133), to 'a rational religion like Christianity' (Otto 1958, 91). The movement of Religionsgeschichte, then, is the same as in Hegel's metanarrative of Geist: Spirit moves away from Natur and comes to pure self-recognition by means of its own externalizations. Otto's history of religion traces out these stages, as Spirit and the holy move from their 'confused' involvement in natural objects and sensations to externalizations which are purer expressions of Spirit's own emancipated character (Wesen). In the exposition that follows, I trace Otto's plot of the history of religion, which, as it turns out, is virtually identical to Hegel's plot for the history of Spirit. It starts with 'primitive' religion (prima, or 'first' in Latin, i.e., closest to nature; Naturvolk in Germanic languages), moves to and through the 'East' and pagan antiquity, and literally culminates in the 'us' to which Otto and Hegel belonged, i.e., Germanic-European Christianity. Each stage of the Entwicklung or development of religious consciousness will be described.

\section{'The Deficient Rationalization and Moralization of Experience': Otto on 'Primitive' Religion}

Our analysis of Otto's narrative of the history of the development of Spirit in the realm of religion will begin by looking at how Otto describes the early phases of the appearance of the holy in history. The holy, or numinous, appears gradually in the pre-history of 'man': the 'numinous only unfolds its full content by slow degrees, as one by one the series of requisite stimuli or incitements becomes operative' (Otto 1958, 132). As noted above, external, 
i.e., natural stimuli are the occasion, not the source or origin, for mind or Spirit to become operative. At first, the holy is 'mixed' with things external to its essence:

In the second place, the 'primitiveness' of the cruder phases is due to the abrupt, capricious, and desultory character which marks the earliest form of numinous emotion; and, in consequence, to its indistinctness, which causes it to be merged and confounded with 'natural' feelings (Otto 1958, 133).

Otto, like Hegel, is not shy about describing 'primitive' religion in derogatory terms. A mind not freed from nature is a barbaric mind, and, while it may potentially claim that which is true of all religion or the true essence of mind as such, it does not begin to actualize this abstract potential. Historical science indicates that the manifestations of the holy at this stage of human history are crude and lack a fully developed moral consciousness:

Finally, and most important, there is the deficient rationalization and moralization of the experience, for it is only gradually that the numinous feeling becomes charged with progressively rational, moral, and cultural significance (Otto 1958, 134).

Like Hegel, Otto closely associates rationality with Spirit. Reason is that part of mind which is truly different from nature and cannot be reduced to nature in any way. Early humanity, though potentially rational, was not actually so, and, as such, religion at this stage lacks both a moral consciousness and sufficient rationality to differentiate itself from the mere nature. Otto concludes: 'These considerations account for the primitive and savage character of the numinous consciousness at its outset' (Otto 1958, 134) - 'the numinous consciousness' and human beings at this stage of development or of history. The plot, then, of Otto's story is the same as Hegel's: Spirit moves away from nature.

The (Feminine) Passivity of the East vs. the (Masculine) Vitality of the Gothic West

Otto's Orientalism

Otto makes a similar argument about the 'East' as he does about 'primitives'. In his book, Mysticism East and West (1932), Otto takes great pains to differentiate, rather than identify, the mysticisms of the 'East' and those of the 
'West'. He uses Śankara as the main representative of the former and Eckhart as the main representative of the latter. He is clear from the first that these two types of religious experience must be sharply differentiated: 'in spite of "convergence of types" between East and West, the inner spirit yet differs, and that the very different ground upon which mysticism rose in Europe also colors the highest mystical experience in a way which is Christian and not Indian' (Otto 1932, 179). Throughout the book he describes many kinds of differences. For our purposes here we will look at only two. First, we will look at the passivity and 'coolness' of temperament of Sankara versus the dynamic and active nature of Eckhart's mysticism. Second, we will look at Otto's view of the differences between Śankara's and Eckhart's views of the godhead. In both cases we will see Otto's use of supposedly rational, scientific, wissenschaftlich methods to assert a quasi-derogatory view of the 'East' and assert the supremacy of his own religion and ethnicity.

Otto says many, many things about the vital activism of Eckhart in contrast to the passivity of Śankara. We cannot detail all of them, but we will start with the issue of 'abstraction'. Otto responds strongly in opposition to the charge that mysticism in general and Eckhart in particular traffic in empty abstractions: 'To say that this "Gothic" personality, absolutely permeated and glowing with the urge of a tremendous new life-impulse, lived in abstractions is absurd' (Otto 1932, 185). On the contrary, this 'Gothic personality' espouses a view that celebrates the vital strength of the living will:

Eckhart's position is neither mystical quietism nor secular activity, but an identity of the deepest unity and the most vivid multiplicity, and therefore of the most profound quiet and most vital motion. It is therefore both a complete inward composure and a most powerful actualization and exercise of the will. (Otto 1932, 191.)

Otto goes further and even explicitly labels this medieval writer a 'voluntarist': 'Thus Eckhart becomes the panegyrist of the strong and active will, and the powerful act - of a voluntarism which alone truly deserves this name' (Otto 1932, 194).

Entailed in this is the argument that Śankara's Indian view is worlddenying while Eckhart's Gothic view is life-affirming: 'For Śankara, the world remains world, painful and miserable, to be fled from, and denied. As we have already seen the result of this attitude is peculiar art of painting the world in pessimistic colors.' (Otto 1932, 229.) By contrast, the 'Gothic personality' Eckhart, in at least partial agreement with that arch-Gothic personality Luther, is world- and life-affirming: 
But Eckhart says: 'I would gladly remain here until the last day.' For him samsāra is already nirvāna, and both become one; he finds joy in the world, radiant with God's light. It is characteristic that with him there are no mournful plaints or lamentations over the world and the body, which play so great a role in Francis, occasionally disfigure Luther's preaching, and are so frequent in Indian philosophy, both in Buddhism and in Hinduism. (Otto 1932, 229.)

In contrast to Śankara's world-denying view, this 'Gothic personality' espouses a kind of Lebensphilosophie:

His mysticism is quiveringly alive and of powerful vitality, and therefore far removed from 'Abstraction'. It is therefore also very far from Śankara and Indian mysticism, and the reason for that difference lies in the foundation from which it rises. In spite of great formal equalities, the inner core of Eckhart is as different from that of Śankara as the soil of Palestine and of Christian Gothic Germany in the thirteenth century is different from that of India. (Otto 1932, 186.)

As Otto makes clear, the differences described here are not merely a matter of individual idiosyncrasies, but are a matter of 'soil', i.e., of differences in national, cultural, and religious character (or 'nature', i.e., Wesen). This is very much the same kind of argument about the differences between India and Europe made by Hegel in The Philosophy of History (see Hegel 1956, 161-167).

We have seen how Otto, following Hegel, argues for a correlation between the stages of human development and their conceptions of divinity. If Otto argues that India is essentially passive and the Gothic West is essentially active, it is not surprising that he will also argue that Śankara's god is passive and inferior while Eckhart's god is active, vital and superior. Again, Otto says many things in this regard and it will not be possible to detail all of them.

One point which Otto makes again and again is that vital activity is essential to the Gothic conception of deity while it is an objection to the Indian conception of deity. Using an old philosophical notion as a point of entry into this discussion: 'The Deity of Eckhart is causa sui, but this not in the merely exclusive sense, that every foreign causa is shut out, but in the most positive sense of a ceaseless self-production of Himself' (Otto 1932, 187). As with Hegel, the outgoing, externalizing moment is an essential component 
of Spirit, of that which differentiates Spirit from mere substance, of that which gives Spirit an inner life, i.e., personality.

By contrast, Śankara finds this inner differentiation and external creativity of the godhead a defect, a falling away from an eternal, immutable perfection:

This [the notion of causa sui described above] is indeed the case with Śankara, for whom the coming forth of God and the world from the primeval oneness of Brahman is the great 'mistake' of Avidyā. But it is not so with Eckhart. God is the wheel rolling out of itself, which, rolling on, not rolling back, reaches its first position again. That it rolls from inward, outward, and inward again is of deep significance. God is, in Himself, tremendous life movement. Out of undifferentiated unity He enters into the multiplicity of personal life and persons, in whom the world and therewith the multiplicity of the world is contained. (Otto 1932, 188.)

Otto makes the contrast clear: 'Is this Brahman a living God? "I am the living God" - that is more than a God who lives.' (Otto 1932, 187.) Insofar as Eckhart's god is mystical it is not because this conception is passive, mere substance, or abstract. Rather: 'This God becomes a mystical God because He is a stream of glowing vitality' (Otto 1932, 187).

In a statement that captures both his argument for the superiority of the Western conception of God and the inferiority of the merely natural, Otto again differentiates the Brahmanic conception of God from the Teutonic:

This God is in Himself a living process, not a static Being. We may here use the word 'process' but only for want of a better, for it as nothing of the nature of any ordinary process. A process is a natural event, but this is no event; it is activity, mighty self-positing, a procreation not under the compulsion of laws or blind impulse but in the creative power and freedom of sublime wonder. (Otto 1932, 188.)

What clearly emerges from this exercise in 'comparative religion' is a replication of the structure of relations as conveyed in the classic image of 'the Orient' as described by Edward Said and others. Again, my argument here is not simply that Otto's exposition of texts is in error, but that his hermeneutical assumptions, whether conscious or unconscious, are predicated upon a hierarchical structural relationship which mirrors nearly perfectly the structure of European colonial relations. He first essentializes 'the East', 
reducing it to a single character, and then shows it to be passive, feminine, and inferior in every sense to an essentialized Gothic West. While others have claimed that Otto is primarily a normative, theological thinker, I am arguing that he does this on the basis of Wissenschaft and that this was a standard practice and almost universally accepted view in the Geisteswissenschaften in general and in Religionswissenschaft in particular.

\section{Plotinus vs. Eckhart: Pagan vs. Christian}

Although he does not develop the theme thoroughly, Otto also insists that, in a manner similar to the critique of Śankara, the Gothic-Christian mysticism of Eckhart transcends the best representative of mysticism in Greco-Roman antiquity, viz., Plotinus:

Here again Eckhart differs completely from Plotinus though he is always represented as his pupil. Plotinus also is the publisher of a mystical love, but his love is throughout not the Christian agápē but the Greek erōs, which is enjoyment, and enjoyment of a sensual and supersensual beauty, arising from an aesthetic experience almost unknown to Eckhart. (Otto 1932, 231.)

Again, by contrast, while the aesthetically and sensual orientation of Plotinus lends itself to a wild emotionalism, which as we saw, is the mark of a less developed spirituality, Eckhart is more like another arch Gothic personality Kant, in effacing emotion even in mystical experience:

Eckhart knows nothing of such emotional orgies or such 'pathological' love (as Kant calls it). For him love is not erōs but the Christian virtue of agápē, strong as death but no paroxysm, inward but of deep humility, at once active in willing and doing as Kant's 'practical' love. (Otto 1932, 231.)

The differentium between Christian agápē and Greek erōs is reason-moralitySpirit. Sensuality is the mark of the less emancipated, less fully realized stage of Spirit or manifestation of the numen. On that basis, as well as on the basis of his own exegesis of Plotinus and Eckhart, Otto positively bristles at the idea that Eckhart might be dependent upon the sensualistic pagan. The Hegelian-Idealist correlations then hold true, even within the West: as Spirit is to nature, as developed is to primitive, as West is to East, so also is Modern to Ancient (and Christian to Pagan) within the West. Just as in Hegel's metanarrative of Spirit, Otto sees the Gothic West as the culmination of Religionsweltgeschichte. 


\section{The Stage of Monotheism: Judaism and Islam vs. Christianity}

\section{The Case of Judaism}

Just as with Hegel and many others, Otto saw the 'arrival' of Spirit at the stage of monotheism as a tremendous advance in its emancipation from nature, its rationalization, and its coming to full self-consciousness. One would think, then, that all monotheisms would receive a different kind of treatment than 'primitive' religion, 'Eastern' religion, or paganism. However, this is not the case. Otto sees deep and basic differences between the three 'major' monotheistic religions, Judaism, Islam, and Christianity. As these differences add significant weight to the thesis that Otto's history of religion mirrors the European colonial situation, a close look at it will be necessary, starting with Judaism.

Like most Christians, Otto had a somewhat ambivalent view of Judaism. On the one hand, it represents a definite stage of progress in the Entwicklung or religious consciousness: 'while the feelings of the non-rational and numinous constitute a vital factor in every form religion may take, they are pre-eminently in evidence in Semitic religion and most of all in the religion of the Bible' (Otto 1958, 72). Semitic monotheism constitutes a radical break with nature religion by holding the divine to be outside nature and its transcendent source. The numinous, however, is both rational and non-rational. With biblical religion, the emergence of a purer form of the numinous can be detected: 'The lower stage of numinous consciousness, viz. daemonic dread, has already been long superseded by the time we reach the Prophets and Psalmists (Otto 1958, 72).

On the other hand, he is quick to make the classic Christian supercessionist argument, i.e., that Christianity both transcends and completes Judaism, albeit in somewhat new terms. Speaking of Jesus, Otto argues as follows:

What of the Lord of this kingdom, the 'heavenly Father'? As its Lord He is not less, but far more 'holy', 'numinous', mysterious [...] and sanctus than His kingdom. He is all these in an absolute degree, and in this aspect of his nature He represents the sublimation and the consummation of all that the old covenant had grasped by way of 'creature-consciousness', 'holy awe', and the like. Not to realize this is to turn the gospel of Jesus into a mere idyll. (Otto 1958, 83.)

We saw above the value Otto places on the philosophical concept of 'personality', i.e., Spirit's inner life and self-reflective nature (as opposed to the 
Indian and pagan notion of mere substance). That concept seems to be what defines the superiority of Christ and Christianity over Judaism: 'Christ had rather to teach and to proclaim what was not self-evident to the Jews, but His own original discovery and revelation, that this very "Holy One" is a "heavenly Father"' (Otto 1958, 83). Fatherhood represents a higher stage of the development of personality than the image of 'lawgiver', so prominent in Mosaic religion, as he argues elsewhere: 'On the one hand was Pharisaism, with its servitude to Law; on the other, John the Baptist, with his harsh, ascetic interpretation of God' (Otto 1958, 83). This thoroughly de-Judaized Jesus represents the via media, a synthesis of these extremes which transcends the limits of both.

\section{The Case of Islam}

If Otto held a somewhat ambivalent view of Judaism, he is unequivocal in his view of Islam. In describing the process by which the numinous is made more rational throughout religious development, he sharply contrasts both Judaic monotheism and Christian personalism with the irrational and retrograde monotheism of Islam:

The culmination of the process [of rationalization] is found in the prophets and in the Gospels. And it is in this that the special nobility of the religion revealed to us in the Bible is to be found, which, when the stage represented by the 'deutero-Isaiah' is reached, justifies its claim to be a universal worldreligion. Here is to be found its manifest superiority over, e.g. Islam, in which Allah is a mere 'numen', and is in fact precisely Yahweh in His pre-Mosaic form and upon a larger scale. (Otto 1958, 75.)

Rather than being the teleological, progressive development of the rationalization of the numinous, which one would expect from his theory of history, for reasons hard to understand from a logical point of view, Otto saw Arabic monotheism as a regression; to him, Islam represents a desultory mixing of sensuous and numinous elements. Contrasting the Quranic notion of predestination with that of Luther, Otto employs rather striking language for a practitioner of Religionswissenschaft:

If it be really true that the consciousness of the numinous, as 'creature-feeling', is the root of the predestination idea, then we should expect that the form of religious faith marked by an undue and exaggerated insistence on the non-rational elements in the idea of God would also lean most markedly 
to predestination. And such is obviously the case. No religion has such a leaning to predestination as Islam; and the special quality of Islam is just that in it, from its commencement onwards, the rational and specifically moral aspect of the idea of God was unable to acquire a firm and clear impress that it won, e.g., in Christianity or Judaism. In Allah the numinous is absolutely preponderant over everything else. So that, when Islam is criticized for giving a merely 'fortuitous' character to the claim of morality, as though the moral law were only valid through the chance of caprice of the deity, the criticism is well justified, only 'chance' and fortuitousness have nothing to do with the matter. The explanation is rather that the numinous in Allah, nay, even his uncanny daemonic character, outweighs what is rational in him. And this will account for what is commonly called the 'fanatical' character of this religion. Strongly excited feelings of the numen, that runs to frenzy, untempered by the more rational elements of religious experience - that is everywhere the very essence of fanaticism. (Otto 1958, 90-91.)

Otto, again, seems here to be reiterating Hegel's theo-anthropogenic thesis: 'An inferior god or a nature god has inferior, natural and unfree human beings as its correlates; the pure concept of God or the spiritual God has as its correlate spirit that is free and spiritual, that actually knows God' (Hegel 1988, 203). The teleological 'arrival' of the stage of monotheism does not, per se, automatically mean that a given group of human beings have emancipated themselves from nature. Otto's argument here clearly indicates that the 'Arab character' is more closely tied to emotion or passion, and thus to Natur, and less tied to reason, and thus to Geist, than is the 'Hebrew character' or the 'Christian character'. So, it is not ultimately a matter of a stage of history or of religious content that determines spirit. It is, apparently, a matter of race. It is not coincidental to this analysis of the structural relations between Judaism, Christianity, and Islam, which seems in many ways to defy Otto's own logic, that Judaism contributes to Christianity and Europe and so is valorized to a degree, while Islam and Arabic civilization have long been held to be the antagonists and rivals of both Christianity and Europe. To anticipate the conclusion of this essay a bit, the analyses of theorists such as Edward Said (e.g., 1978), describe the functioning of the system of representations created by Western scholars, including Otto and Religionswissenschaft, as a hierarchy of correlative concepts: Islam must be irrational if Christianity is to be rational. Judaism must be legalistic if Christianity is to be the consummate religion of love. We will return to these issues in the conclusion. 


\section{The Supremacy of Christianity.}

By contrast, in its combination of elements of 'pure reason' with outward expressions, the Christian religion 'with its peculiar and unique content of belief and feeling, standing in all its historical greatness and supremacy when measured against other religions' (Otto 1958, 163) 'shows its superiority over others. It is a more perfect religion and more perfectly religious than they, in so far as what is potential in religion in general becomes in Christianity a pure actuality.' (Otto 1958, 56.) Because, as argued above,

we count this the very mark and criterion of a religion's high rank and superior value - that it should have no lack of conceptions about God; that it should admit knowledge - the knowledge that comes by faith - of the transcendent in terms of conceptual thought [...] Christianity not only possesses them in unique clarity and abundance, and this is, though not the sole or even the chief, yet a very real sign of its superiority over religions of other forms and at other levels. (Otto 1958, 1.)

If the self-actualization of Spirit comes, as Hegel had said, in 'pure selfrecognition in absolute otherness', then Natur is the necessary vehicle for Spirit. Consequently, the highest stage of Spirit is not the absence of nature, but the perfect synthesis of Natur and Geist. This is realized in Christianity as it is in no other religions. Other religions are either too enmeshed in nature or too abstract.

The same point applies to moral concepts. Otto goes to great pains, as had Schleiermacher before him, to show that religion is not the same thing as morality. However, both are part of the rational, immaterial, non-natural essence of Spirit, and so advances in Spirit will correlate with advances in conceptions of the holy as well as moral concepts. In this too Christianity proves its supremacy over other religions:

No religion has brought the mystery of the need for atonement or expiation to so complete, so profound, or so powerful expression as Christianity. And in this, too, it shows its superiority over others. It is a more perfect religion and more perfectly religion than they, in so far as what is potential in religion in general becomes in Christianity a pure actuality. (Otto 1958, 56.)

As with Hegel, Christianity is the consummation of religion as such, of that a priori, timeless, universal essence of mind, consciousness, 'man', or Spirit. It is the telos and endpoint of all history, i.e., not merely the history of one 
civilization among others, but Allgemeingeschichte. The destiny of humanity ends, according to Otto and Hegel alike, with and in Germanic-European Christianity - a view that both reflects perfectly the historical situation of European colonization and legitimates that situation.

\section{Conclusion}

On the one hand, the very nature of the idea of an a priori category would seem to move in an egalitarian, universalistic, and inclusive direction, and Otto does famously state that: 'There is no religion in which [the idea of the holy] does not live as the real innermost core, and without it no religion would be worthy of the name' (Otto 1958, 6). On the other hand, Otto draws the logical consequence of this sequence of claims, from his analysis of the 'holy' as a 'pure' a priori category (i.e., belonging to Spirit), to its manifestation throughout history, which also, as with Hegel, is the history of Geist's gradual emancipation from Natur:

For nothing is more clearly taught by a comparison of religions than this: the qualitative difference of religions in their higher stages. There is no single thing which marks the difference between man and man so penetratingly as his religion; neither race, nor climate, nor way of life can compare with it. (Otto 1931, 202-203.)

Comparing Hinduism with Christianity, he continues:

There is an unlikeness in a human being who conceives and has an inward experience of the Eternal Being as an omnipotent Karma urging from birth to birth, with an ever-recurring agony of the lust for life, who finds salvation in a blissful cessation of the desire for existence; and in another who has experience of it as an official of the law, auditing one's own life in a debit and credit of 'good works'; and an absolute unlikeness in another, who has experience of it as the 'Father of Jesus Christ'. (Otto 1931, 203.)

While it would seem that the universalistic tendency of terms like 'Geist', 'man', 'essence', 'a priori', etc., would tend towards a more egalitarian view of religion, precisely the opposite is the case.

Such a colonialist-discourse reading of Otto's The Idea of the Holy would seem to be necessary given the dominant tendency in Religious Studies to valorize the insider, empathetic approach of Otto and depoliticize his theory. One scholar, who describes herself as a Jewish feminist, argues in a recent 
book for 'the inclusivity of The Idea of the Holy' (Raphael 1997, 7), claiming that 'Otto's concept of holiness proposes an egalitarian anthropology' (Raphael 1997, 8) and that 'The Idea of the Holy is [...] socially and historically disengaged' (Raphael 1997, 7); and that, moreover, 'whilst Otto's concept of holiness is heavily dependent on Western philosophical categories and his own Lutheran tradition, it is never parochial. The close relation of his phenomenology and his theology entails that Otto imposes no obligation of choice between one's own tradition and another, or any [...] tests of spiritual loyalty' (Raphael 1997, 7). Such are the kind of scholarly hermeneutics one encounters in the field of Religious Studies, an academic field which has arguably been more interested in 'inter-faith dialogue' than in critical scholarship.

To widen out a bit, let us ask a question: 'But why this emphasis on Hegel?' (Young 1990, 3). Robert Young poses a question which would seem pertinent at this juncture. The answer, as Young explains, has to do with Hegel's relationship to Western imperialism: 'Hegel articulates a philosophical structure of the appropriation of the other as a form of knowledge which uncannily simulates the project of nineteenth-century imperialism' (Young 1990, 3). The emphasis on Hegel and on the correlation between Hegel and Otto allows a reading to see what Melissa Raphael (quoted above), cannot see: the relationship between Religionswissenschaft and colonialism. By contrast, if we adopt colonial discourse analysis provisionally as a strategy of reading texts, what becomes clear is this: as all meaning is constituted by the specific series of relations in a text, these terms assume structural positions relative to one another. These relations are rarely, if ever, homologous, as Mark Taylor has argued:

Invariably one term is privileged through the divestment of its relative. The resultant economy of privilege sustains an asymmetrical hierarchy in which one member governs or rules the other throughout the theological, logical, axiological, and even political domains. (Taylor 1984, 9.)

It is this 'economy of privilege' that has been characteristic of the 'power/ knowledge' correlation manifest in the structures created by Otto's way of opposing Spirit and Nature and in his empottment of the history of religion.

This strategy of reading texts is informed by the kinds of questions which the specifically poststructuralist form of postcolonial theory has been asking of Western discourse. This was exactly the late Edward Said's point in his groundbreaking work, Orientalism: 
Is there any way of avoiding the hostility expressed by the division, say, of men into 'us' (Westerners) and 'they' (Orientals). For such divisions are generalities whose use historically and actually has been to press the importance of the distinction between some men and some other men, usually towards not especially admirable ends [...] the result [of such a distinction] is usually to polarize the distinction - the Oriental becomes more Oriental, the Westerner more western [...]. (Said 1978, 45-46.)

Ania Loomba, in a more recent work, has made a very salient point about Said's analysis, one that shows the profound implications of the method described by Taylor above. In the system of representations created by Western scholars, a hierarchy of correlative concepts emerges:

Said shows that this opposition [between the West and the Orient, as described above] is crucial to European self-conception: if colonized people are irrational, Europeans are rational; if the former are barbaric, sensual, and lazy, Europe is civilization itself, with its sexual appetites under control and its dominant ethic that of hard work; if the Orient is static, Europe can be seen as developing and marching ahead; the Orient has to be feminine so that Europe can be masculine. (Loomba 1998, 47.)

A poststructuralist-postcolonial reading of Otto (et al.) allows us translate his abstract, metaphysical conceptual dichotomies, such as a priori/a posteriori, Spirit/Nature, sense/reason, into a kind of veiled speech about historically real social groups: Indians, Chinese, Africans, Native Americans and so forth. We can then see the logocentric, Eurocentric, and Christocentric tendencies as these are expressed in Otto's famous and oft cited work, The Idea of the Holy - and of Religious Studies as a field of 'knowledge' insofar as it has been influenced by Otto. If the matter were merely 'academic', or a matter of an abstract system of concepts, this would be one thing. However, applied to real human groups as Otto does, the metanarrative of Geist, whether articulated diachronically or synchronically, is simply and factually a narrative of the supremacy - his term, not mine - of white, Christian Europe over black, 'primitive' Africa and a movement away from brown or yellow, 'despotic' Asia. It moves from the South to the North; away from the East to the West. It moves out of Africa and into Germany; out of Asia, through Greece and into the heart of Europe. It moves away from 'nature' to 'spirit'; out of bondage to freedom, it transcends 'law' and culminates in 'love', and goes beyond 'sensualism' to 'pure reason'. And this narrative, this metaphysics 
of the subject, of Geist, of 'man' works thus whether or not its 'articulator' is 'personally' racist or prejudiced, whether or not they are, in any sense of the terms, 'liberal' or conservative, whether or not they are believers or atheists, whether or not they consider themselves theologians or historians, whether or not they praise Hegel or damn him, whether they are known by the names of Schleiermacher, Dilthey, Tiele, Otto, van der Leeuw, Wach, or Eliade. This is a racist, colonialist discursive structure, more virulent at times, less at others admittedly, but racist nonetheless. It professes a universalism; but, in the end, time and time again, uses that very same universalism to marginalize the already marginal and denigrate the already denigrated in the silent-so-all-the-more-insidious constant reiteration of its logocentric, Eurocentric and Christocentric colonialist hegemony. When its core, constitutive, structural oppositions are unmasked, it is seen to be the vicious, self-aggrandizing, and monstrously narcissistic ideological formation that it is, an ideological formation not only potentially heinous in its practical effects, but also, from a scientific point of view, patently false.

Several questions remain: to what extent does the underlying system of concepts, e.g., 'religion', 'consciousness', 'man', 'a priori', 'sui generis', etc., continue to be operative in Religious Studies? To what extent does such a system of concepts continue to carry embedded within its history and structure implicit colonialist assumptions together with the colonialist 'economy of privilege'? By extension, to what extent is the very 'curriculum', in the broadest sense, of Western universities still invested in, predicated upon, Hegel's metanarrative? Has colonialism's distorting influence really disappeared or has a neo-colonialism become silently embedded in the very structures of that which we in the West call 'knowledge'?

Bibliography

Almond, Phillip C.

1984 Rudolf Otto: An Introduction to his Philosophical Theology. Chapel Hill: The University of North Carolina Press.

\section{Davidovich, Adina}

1993 Religion as a Province of Meaning. Minneapolis: Fortress Press.

Hegel, G. W. F.

1956 The Philosophy of History. J. Sibree (trans.). New York: Dover Publications. 
1977 Phenomenology of Spirit. A.V. Miller (trans.). Oxford: Oxford University Press.

1988 Lectures on the Philosophy of Religion. R. F. Brown, P. C. Hodgson, and J. M. Stewart (trans.). Berkeley: University of California Press.

\section{Idinopulous, Thomas A.}

1994 Must Professors of Religion be Religious? On Eliade's Method of Inquiry and Segal's Defense of Reductionism. - Thomas Idinopulos \& Edward Yonan (eds), Religion and Reductionism: Essays on Eliade, Segal, and the Challengeof the Social Sciences for the Study of Religion, 65-81. Leiden: E. sJ. Brill.

\section{Loomba, Aina}

1998 Colonial/Postcolonialism. London and New York: Routledge.

Otto, Rudolph

1907 Naturalism and Religion. J. Arthur Thomson \& Margaret R. Thomson (trans.). New York: G. P. Putnam's Sons.

1931 The Philosophy of Religion. E. B. Dicker (trans.). London: Williams and Norgate.

1932 Mysticism East and West. Bertha L. Bracey \& Richenda C. Payne (trans.). New York: The Macmillan Company.

1958 (1917) The Idea of the Holy: An Inquiry into the Non-Rational Factor in the Idea of the Divine and Its Relation to the Rational. J. W. Harvey (trans.). Oxford: Oxford University Press.

\section{Raphael, Melissa}

1997 Rudolf Otto and the Concept of Holiness. Oxford: Clarendon Press.

\section{Taylor, Mark C.}

1984 Erring: A Postmodern A/Theology. Chicago: University of Chicago Press.

\section{Said, Edward W.}

1978 Orientalism. New York: Vintage Books.

\section{Young, Robert}

1990 White Mythologies: Writing History and the West. London and New York: Routledge. 
